\title{
EDUKASI KANKER PAYUDARA DAN DETEKSI DINI PADA KADER WANITA KELURAHAN TOMANG
}

\author{
Chrismerry Song $^{1}$, Sony Sugiharto ${ }^{2}$ dan Octavia Dwi Wahyuni ${ }^{3}$ \\ ${ }^{1}$ Fakultas Kedokteran, Universitas Tarumanagara, Jakarta \\ Email: chrismerrys@fk.untar.ac.id \\ ${ }^{2}$ Fakultas Kedokteran, Universitas Tarumanagara, Jakarta \\ Email:marias@fk.untar.ac.id \\ ${ }^{3}$ Fakultas Kedokteran, Universitas Tarumanagara, Jakarta \\ Email: octaviaw@fk.untar.ac.id
}

\begin{abstract}
Breast cancer is the most common cancer in women. In Indonesia, the incidence of breast cancer is 42.1 per 100,000 population with an average death rate of 17 per 100,000 population. Age is a major risk factor for breast cancer. Incidence will increase as a person ages, but now, breast cancer is starting to be common at young age. Treatment cost is very large, so health promotion and early detection are very important. Early detection can be done with BSE (Breast Self Exam). Health education is one way to increase knowledge and BSE training can make breast cancer found at an early stage so morbidity and mortality can be reduce. There were 47 PKK administrators and female cadres of Tomang Village participated. Respondents ages 22-76 years with a mean of 48 years. Most of the participants thought the material was easy to understand, as expected, information conveyed was clear, speaker mastered the topic and could answer questions well and clearly, discussions helped improve participants' understanding, time allocation was sufficient, and this counseling was useful. Most of the participants also can do BSE after counseling and will teach BSE to other residents. There was an increase in the level of knowledge of participants after the counseling. It is hoped that through this activity, breast cancer cases can be known more quickly so that they can be treated as soon as possible.
\end{abstract}

Keywords: breast cancer, health education, knowledge, BSE

Kanker payudara merupakan kanker yang paling banyak ditemukan pada perempuan di dunia dan di Indonesia. Di Indonesia angka kejadian kanker payudara 42,1 per 100.000 penduduk dengan rata-rata kematian 17 per 100.000 penduduk. Usia merupakan faktor risiko mayor terjadinya kanker payudara, dengan meningkatnya usia insiden kanker payudara meningkat, namun makin sering ditemukan penderita kanker payudara berusia muda. Biaya pengobatan kanker payudara sangat besar sehingga promosi kesehatan dan deteksi dini menjadi sangat penting. Deteksi dini kanker payudara dapat dilakukan dengan SADARI. Edukasi kesehatan merupakan salah satu cara untuk meningkatkan pengetahuan tentang kanker payudara dan pelatihan cara melakukan SADARI dapat membuat kanker payudara ditemukan dalam stadium dini sehingga dapat menurunkan morbiditas dan mortalitasnya. Penyuluhan diikuti 47 orang pengurus PKK dan kader wanita Kelurahan Tomang secara daring. Rentang usia responden adalah 22 - 76 tahun dengan rata-rata 48 tahun. Hasil kuesioner didapatkan sebagian besar peserta berpendapat materi mudah dipahami, sesuai harapan, informasi yang disampaikan jelas, pembicara menguasai topik serta dapat menjawab pertanyaan dengan baik dan jelas, diskusi membantu meningkatkan pemahaman peserta, alokasi waktu penyampaian materi maupun diskusi mencukupi, dan penyuluhan ini bermanfaat. Sebagian besar peserta dapat melakukan SADARI setelah penyuluhan dan akan mengajarkan SADARI kepada warga Tomang lainnya. Terlihat adanya peningkatan tingkat pengetahuan peserta setelah penyuluhan. Diharapkan melalui pengenalan tanda-tanda kanker payudara, SADARI, dan rujukan yang tepat, kasus kanker payudara dapat diketahui lebih cepat sehingga mendapatkan penanganan sesegera mungkin.

Kata kunci: kanker payudara, edukasi kesehatan, pengetahuan, SADARI

\section{PENDAHULUAN}

Payudara adalah organ penting yang terletak pada otot pektoralis yang berada di dada, dan melindungi ligamen serta jaringan ikat. Baik pria dan wanita memiliki payudara yang berkembang sebelum dilahirkan, namun jaringan payudara wanita lebih signifikan karena perbedaan anatomi dan terus menerus terpapar dengan hormon yang memicu pertumbuhannya, terutama saat mengandung. Selain peran dalam aktivitas seksual, payudara juga berfungsi sebagai sarana memberikan air susu ibu (ASI) untuk bayi, sehingga kondisi kesehatannya harus diperhatikan dengan baik. Berbagai kelainan dapat ditemukan pada payudara, mulai dari sekedar kelainan 
anatomis sampai menimbulkan gejala kemerahan, rasa nyeri, pembengkakan atau adanya benjolan. Banyak faktor dapat menjadi penyebabnya seperti faktor genetik, infeksi, trauma, juga pertumbuhan sel yang abnormal seperti tumor jinak maupun ganas. Umumnya kelainan payudara terjadi pada perempuan pada berbagai tahapan usia, namun dapat terjadi juga pada pria. Pada wanita, hanya 3-6\% tumor payudara yang bersifat ganas, sebagian besar jinak. Pada usia 30-an, $50 \%$ kelainan berupa mastalgia dan fibrocystic changes, sedangkan $25 \%$ adalah fibroadenoma (Stachs et al., 2019). Pada wanita menyusui dapat terjadi mastitis dan galactocele (Haliloglu et al., 2019). Kelainan payudara laki-laki dapat berupa ginekomastia dan kanker payudara, walaupun jarang terjadi (Johnson \& Murad, 2009). Umumnya perubahan pada payudara pria lebih mudah dikenali sehingga penderita akan langsung mencari penanganan lebih lanjut.

Penyakit kanker merupakan salah satu penyakit tidak menular yang menjadi beban kesehatan di seluruh dunia, yang ditandai dengan adanya sel yang abnormal yang dapat berkembang tanpa terkendali dan memiliki kemampuan untuk menyerang dan berpindah antar sel dan jaringan tubuh. World Health Organization (WHO) bahkan menyebutkan kanker sebagai salah satu penyebab kematian utama di seluruh dunia. Menurut Globocan 2018, di dunia kanker payudara merupakan kanker yang paling banyak ditemukan pada perempuan, yaitu 24,2\% dari 8,6 juta kasus baru dengan angka mortalitas sebesar 15\% dari 4,2 juta kematian akibat kanker (Bray et al., 2018). Data Globocan 2020 menunjukkan hal yang sama, dengan insidens sebesar 24,5\% dari 9,2 juta kasus baru dan angka mortalitas 15,5\% dari 4,4 juta kematian akibat kanker, seperti yang tampak pada Gambar 1 (Sung et al., 2021). Terlihat jelas bahwa terjadi peningkatan jumlah kasus baru maupun angka kematian dalam kurun waktu 2 tahun.

Di Indonesia, kanker payudara juga merupakan jenis kanker terbanyak yang dijumpai pada wanita. Angka kesakitan kanker di Indonesia menggambarkan pola yang sama dengan pola yang terjadi dunia. Data yang bersumber dari RS Kanker Dharmais tahun 2018 menunjukkan bahwa kasus kanker terbanyak adalah adalah kanker payudara sebesar 19,18\%, kanker serviks sebesar 10,69\%, dan diikuti kanker paru-paru sebesar 9,89\% (Kementerian Kesehatan RI, 2019). Data lain memperlihatkan angka kejadian untuk perempuan yang tertinggi adalah kanker payudara yang menempati urutan pertama dengan angka kejadian 42,1 per 100.000 penduduk dengan rata-rata kematian 17 per 100.000 penduduk diikuti kanker serviks dengan angka kejadian 23,4 per 100.000 penduduk dengan rata-rata kematian 13,9 per 100.000 penduduk (Kementerian Kesehatan RI, 2019). Hal yang sama tampak dalam data Globocan 2020, kanker payudara sebagai penyebab kanker terbanyak pada wanita (30,8\%), maupun pada kedua jenis kelamin (16,6\%) di Indonesia, seperti yang terlihat pada gambar 2 (The Global cancer observatory, 2020).

\section{Gambar 1}

Distribusi Jumlah Kasus dan Kematian 10 Jenis Kanker Paling Umum pada Wanita di Dunia Tahun 2020 (sumber: GLOBOCAN, 2020)

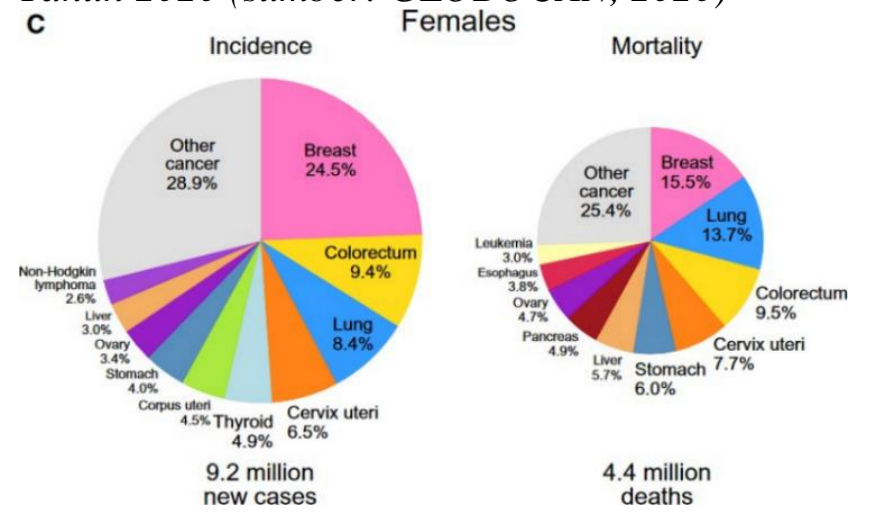




\section{Gambar 2}

Jumlah kasus Baru Kanker di Indonesia pada Tahun 2020 (sumber: GLOBOCAN 2020)

Number of new cases in 2020 , both sexes, all ages

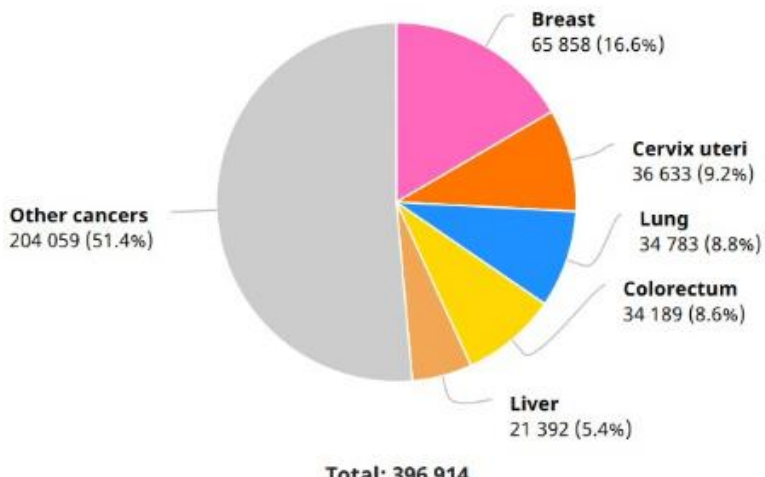

Total: 396914
Number of new cases in 2020, females, all ages

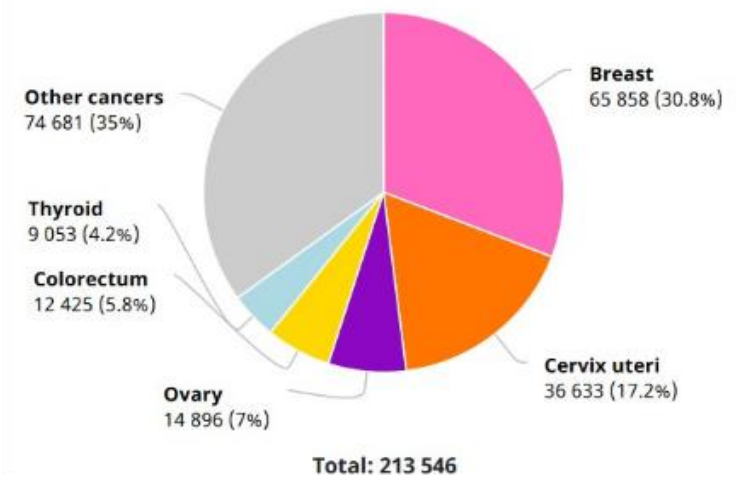

Berbagai kondisi dapat menjadi faktor risiko terjadinya kanker payudara pada seseorang, antara lain jenis kelamin, usia, haid pertama (menarche) pada usia kurang dari 12 tahun, wanita yang tidak menikah, wanita menikah tetapi tidak memiliki anak, melahirkan anak pertama pada usia 30 tahun, tidak menyusui, menggunakan kontrasepsi hormonal dan atau mendapat terapi hormonal dalam waktu yang cukup lama, menopause pada usia lebih dari 55 tahun, pernah menjalani operasi tumor jinak payudara, riwayat kanker dalam keluarga, wanita yang mengalami stres berat, berat badan berlebih, kebiasaan mengonsumsi lemak dan alkohol secara berlebih, maupun perokok aktif dan pasif (Breast Cancer Risk Factors, 2020; Sung et al., 2021). Jenis kelamin merupakan salah satu faktor risiko yang signifikan untuk terjadinya kanker payudara. Walaupun pria juga dapat menderita kanker payudara, namun wanita memiliki risiko yang lebih besar karena sel payudaranya terus berubah dan berkembang akibat pengaruh aktivitas hormon estrogen dan progesteron. Usia adalah faktor risiko terbesar kedua. Semakin meningkat usia, maka semakin meningkat pula insiden kanker payudara. Namun belakangan ini, tampak bahwa kejadian kanker payudara mulai meningkat pada usia remaja. Hal ini mungkin disebabkan pengaruh gaya hidup, kurangnya konsumsi sayur dan buah, merokok, dan konsumsi alkohol. Komposisi diet yang tidak seimbang saat pubertas disertai gaya hidup yang tidak sehat berkontribusi terhadap kejadian kanker payudara di kemudian hari, karena gizi merupakan salah satu faktor yang memengaruhi kadar esterogen dan estradiol dalam tubuh (YKPI, 2013).

Di negara-negara Asia yang penduduknya berpenghasilan rendah dan menengah, usia penderita kanker payudara lebih muda daripada di negara maju, berkisar antara 40 - 54 tahun (Fan et al., 2015). Di Indonesia, distribusi kanker payudara di RS Sardjito 35,81\% pada kelompok usia 41-50 tahun, 30,69\% pada kelompok usia 51-60 tahun dan 14,29\% pada kelompok usia 31-40 tahun (RKBR, n.d.). Faktor keterlambatan deteksi menjadi salah satu hal yang berperan dalam kasus kanker payudara. Semakin cepat deteksi, maka pengobatan dapat segera dilakukan, sehingga prognosis akan lebih baik. Walaupun kanker payudara kerap terjadi baik di negara maju dan berkembang, namun kasusnya lebih tinggi di negara berkembang, di mana pendapatan ekonomi masyarakatnya lebih rendah. Kondisi ini berkontribusi terhadap memburuknya penyakit, karena kecenderungan masyarakat di negara berkembang yang baru memeriksakan kondisinya saat sudah stadium akhir. Keterlambatan ini juga berpengaruh terhadap bertambahnya biaya pengobatan. Salah satu penelitian di Makassar menunjukkan seorang penderita kanker payudara menghabiskan biaya rata-rata Rp. 50,292,625.-. Ini tentunya menjadi beban berat untuk penderita dan pemerintah, sehingga promosi kesehatan dan deteksi dini menjadi sangat penting (Palu et al., 2013). 
Ada 4 pilar penanggulangan kanker yang dikemukakan oleh Kementerian Kesehatan RI, yaitu promosi/ edukasi kesehatan kepada masyarakat, deteksi dini, perlindungan khusus seperti vaksinasi (baru ada untuk pencegahan kanker serviks), pengobatan(Kementerian Kesehatan RI, 2020). Untuk kanker payudara, deteksi dini dapat dilakukan dengan metode SADARI (pemeriksaan payudara sendiri) dan SADANIS (pemeriksaan payudara klinis). Metode SADARI merupakan salah satu cara untuk mengetahui ada tidaknya kelainan pada payudara yang dilakukan sendiri, sedangkan SADANIS dilakukan oleh tenaga kesehatan yang terlatih seperti dokter atau bidan. Tujuan pemeriksaan tersebut adalah untuk menemukan benjolan dan tanda-tanda lain pada payudara sedini mungkin agar dapat dilakukan tindakan secepatnya. Pemeriksaan SADARI direkomendasikan sejak wanita berusia 20 tahun dengan dilakukan sendiri di rumah setiap bulannya. Bagi wanita yang masih haid, pemeriksaan dilakukan setiap hari ke-7 sampai 10, dihitung mulai dari hari pertama haid atau setiap bulan pada tanggal yang sama bagi yang sudah menopause (Kementerian Kesehatan RI, 2015). Tindakan ini sangat penting karena hampir 85\% benjolan di payudara ditemukan oleh penderita sendiri. Dalam riset Penyakit Tidak Menular (PTM) tahun 2016 yang dilakukan pada 43.948 penduduk perempuan berusia 25-64 tahun di daerah perkotaan Indonesia tampak bahwa perilaku masyarakat dalam deteksi dini kanker payudara masih rendah. Tercatat hanya $46,3 \%$ pernah melakukan SADARI, dan 4,4\% pernah melakukan SADANIS. Sementara tindak lanjut dari hasil SADARI terakhir kali yang tertinggi adalah tidak melakukan apa-apa $(80,3 \%)$, periksa berkala $(13,8 \%)$, periksa ke dokter $(4,8 \%)$. Dari jumlah penduduk yang tidak melakukan SADARI, proporsi alasan paling banyak adalah karena tidak tahu $(34,8 \%)$ dan tidak ada keluhan $(33,2 \%)$, sedangkan yang tidak tahu cara melakukan SADARI sebanyak $8,8 \%$. Dari 42190 penduduk yang tidak melakukan SADANIS, alasan terbanyak adalah karena tidak ada keluhan $(52,9 \%)$ dan tidak tahu $(26,0 \%)$, tetapi masih ada sekitar 0,5-0,6\% yang beralasan takut nyeri, malu, dan biaya mahal (Kementerian Kesehatan RI, 2016). Hal ini memperlihatkan masih rendahnya pengetahuan maupun tingkat kesadaran masyarakat dalam melakukan deteksi dini kanker payudara.

\section{Permasalahan mitra dan solusi}

Kelurahan Tomang merupakan salah satu kelurahan yang ada di Kecamatan Grogol Petamburan, Jakarta Barat, dengan luas wilayah sekitar 1,88 $\mathrm{Km}^{2}$. Total penduduknya 35.299 jiwa (7.852 KK) dengan jumlah penduduk perempuan 18.333 (51.9\%). Kelurahan ini terdiri dari 174 RT dan 16 RW (Dinas komunikasi, 2017; Badan Pusat Statistik, 2021). Hanya ada 1 puskesmas kecamatan sebagai fasilitas kesehatan, sehingga dibutuhkan peran serta masyarakat dalam mengupayakan terciptanya kehidupan yang sehat sejahtera. Tim penggerak PKK (Pemberdayaan Kesejahteraan Keluarga) Kelurahan Tomang merupakan sebuah organisasi kemasyarakatan sekaligus mitra kerja Pemerintah Kelurahan Tomang yang berfungsi sebagai fasilitator, perencana, pelaksana, pengendali dan penggerak pada masing- masing jenjang demi terlaksananya 10 Program Pokok PKK, salah satunya adalah kesehatan, di seluruh wilayah Kelurahan Tomang (TP PKK Tomang, n.d.). Hasil tanya jawab dengan beberapa kader memperlihatkan bahwa budaya malu dan tabu menjadi penghambat sebagian besar perempuan untuk mencari pengetahuan tentang payudara, yang berakibat minimnya pengetahuan mengenai kanker payudara. Di samping itu, masih sedikit perempuan yang melakukan SADARI secara rutin, dan cenderung mendiamkan atau mencari pengobatan di luar medis saat mereka mendapatkan adanya benjolan pada payudara, belum lagi mitos-mitos yang beredar di masyarakat, misalnya pengangkatan seluruh payudara jika ditemukan benjolan; semuanya dapat membuat keterlambatan diagnosis sehingga kanker payudara ditemukan dalam stadium lanjut dan lebih sulit ditangani.

Fakultas Kedokteran Universitas Tarumanagara (FK Untar) adalah salah satu institusi pendidikan terkemuka dan berpengalaman, serta selalu menunjukkan kepedulian terhadap kualitas masyarakat, 
terutama masyarakat sekitarnya. FK Untar terletak di Kelurahan Tomang, dan kelurahan tersebut merupakan salah satu daerah binaan Universitas Tarumanagara. Banyak kader PKK Kelurahan Tomang juga menjalin kerjasama sebagai pasien simulasi dalam kegiatan pembelajaran di FK Untar. Solusi yang dibutuhkan untuk mengatasi kondisi di atas adalah memberikan edukasi kesehatan mengenai kanker payudara dan deteksi dininya kepada kader-kader wanita di Kelurahan Tomang, yang dilakukan melalui penyuluhan dan pelatihan melakukan SADARI oleh tim PKM FK Untar. Tujuannya adalah untuk menambah pengetahuan para kader wanita mengenai kanker payudara, cara mendeteksi dini, dan apa yang harus dilakukan setelahnya, sehingga diharapkan kejadian tumor/ kanker payudara dapat diketahui dan ditangani lebih cepat, dan pengetahuan ini dapat dibagikan kepada keluarga-keluarga yang ada di Kelurahan Tomang. Untuk ke depannya, diharapkan juga program ini dapat menurunkan jumlah penderita kanker payudara, memperbaiki prognosis, serta meningkatkan kualitas hidup mereka.

\section{METODE PELAKSANAAN PKM}

Kegiatan ini diberikan dalam bentuk edukasi kesehatan secara daring dengan bantuan media visual yaitu power point, aplikasi zoom meeting, dan video rekaman. Sasaran kegiatan adalah kader wanita Kelurahan Tomang. Topik penyuluhan adalah "Edukasi kanker payudara dan deteksi dini pada kader wanita Kelurahan Tomang". Materi disampaikan oleh dokter spesialis Patologi Anatomi yang merupakan dosen FK Untar. Mahasiswa bertindak sebagai co-host dalam zoom meeting, juga membagikan link kuesioner kepada seluruh peserta. Kuesioner bertujuan untuk mengetahui tingkat pengetahuan dan kepuasan peserta terhadap kegiatan PKM. Waktu yang diberikan untuk pengisian kuesioner adalah 10 - 20 menit. Presentasi materi berlangsung sekitar 30 - 45 menit, dilanjutkan sesi tanya jawab sekitar 30 menit. Demonstrasi SADARI ditunjukkan melalui video yang telah disiapkan, dilanjutkan dengan praktik, dibantu 2 instruktur yang merupakan dosen FK Untar juga, dimana narasumber meminta interaksi peserta untuk memraktekkan kembali cara SADARI. Memori akan bertahan lebih lama jika informasi disampaikan berulang kali, maka kami juga memberikan poster sesuai topik edukasi berisi langkah dan cara SADARI sesuai referensi Permenkes. Kami berharap pihak mitra dapat menerapkannya dalam pola hidup sehari-hari sehingga akan menjadi suatu kebiasaan.

\section{HASIL DAN PEMBAHASAN}

Kegiatan ini diikuti oleh 47 peserta yang terdiri dari pengurus PKK dan kader-kader wanita di Kelurahan Tomang. Edukasi berlangsung pada hari Sabtu, 13 Maret 2021 pk. 08.00 - 11.00 WIB melalui zoom meeting. Kegiatan diawali dengan pengisian daftar hadir dan pre-test melalui google form yang telah disiapkan oleh panitia. Acara dibuka dengan sambutan dari ketua tim PKM, dilanjutkan dengan foto bersama dan penyerahan poster kesehatan secara simbolis kepada mitra (gambar 3), dilanjutkan dengan penyuluhan oleh narasumber dan sesi tanya jawab (gambar 4), lalu demonstrasi SADARI melalui video dan hands on SADARI oleh peserta (gambar 5). Kegiatan ditutup dengan pengisian post-test dan kuesioner kepuasan oleh peserta.

Seluruh kegiatan diikuti dengan antusias oleh peserta, terlihat dari banyaknya pertanyaan yang diajukan oleh peserta, dan keaktifan peserta dalam hands on SADARI. Narasumber memilih 3 (tiga) orang peserta secara acak untuk melakukan SADARI, dan peserta dapat melakukannya dengan baik. Kuesioner kepuasan diberikan setelah penyuluhan, sebanyak 47 kuesioner terisi dan valid. Peserta terdiri dari pengurus PKK dan kader. Usia responden termuda adalah 22 tahun, tertua 76 tahun, dengan rata-rata 48 tahun. Sebagian besar responden berusia antara $46-65$ tahun, yaitu $25(53,19 \%)$ orang. Sebagian besar peserta $(61,70 \%)$ memiliki tingkat pendidikan SMA. Hasil kuesioner didapatkan sebanyak 39 (82,98\%) peserta berpendapat materi mudah dipahami, materi sesuai harapan, informasi yang disampaikan jelas, pembicara menguasai topik dan dapat 
menjawab pertanyaan dengan baik dan jelas, diskusi membantu meningkatkan pemahaman peserta, alokasi waktu penyampaian materi dan diskusi mencukupi. Sebanyak $39(82,98 \%)$ orang dapat melakukan SADARI setelah penyuluhan dan sebanyak $37(78,72 \%)$ orang akan mengajarkan SADARI kepada warga Tomang lainnya. Sebanyak 39 (82,98\%) responden menganggap penyuluhan ini bermanfaat. Karakteristik responden selengkapnya dapat dilihat pada Tabel 1.

\section{Gambar 3}

Sambutan dan Penyerahan Poster Secara Simbolis

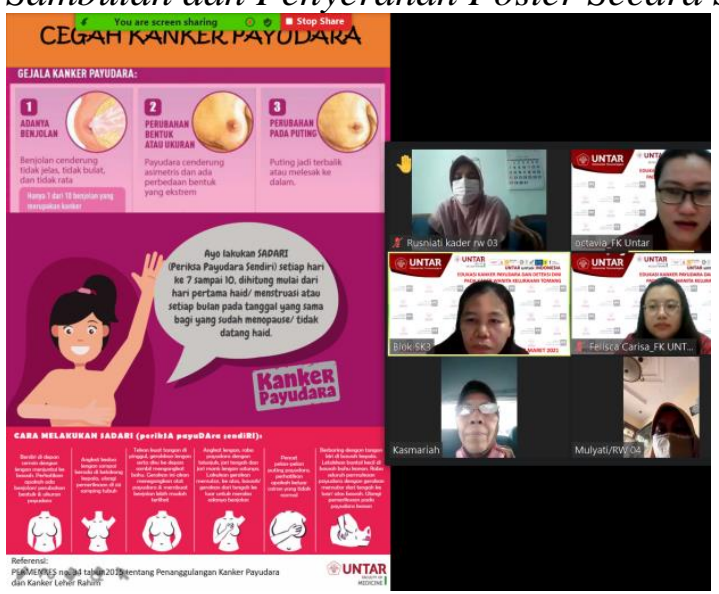

\section{Gambar 4}

Pemaparan oleh Narasumber dan Sesi Tanya Jawab yang Dipandu Oleh MC

Kanker Payudara

- Paling banyak pada perempuan di Dunia dan Indonesia

- 42,1 per 100.000 penduduk; kematian 17 per 100.000 penduduk. (KEMENKES 2019)

- $66,5 \%$ pada usia $41-60$ Tahun, $4-6 \%<40$ tahun

- Semua usia 10-97 tahun

- Perempuan dan laki-laki
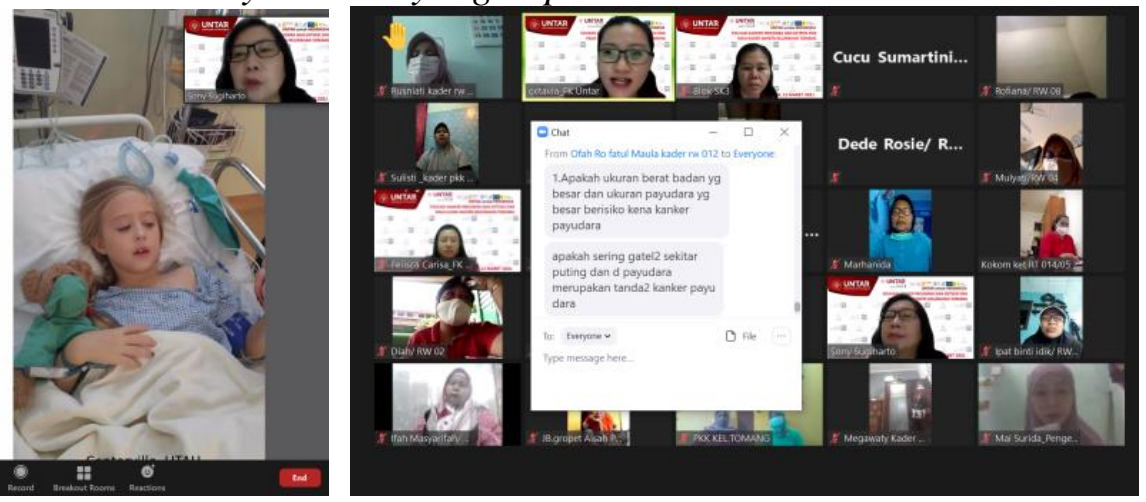

\section{Gambar 5}

Demonstrasi dan Hands On SADARI
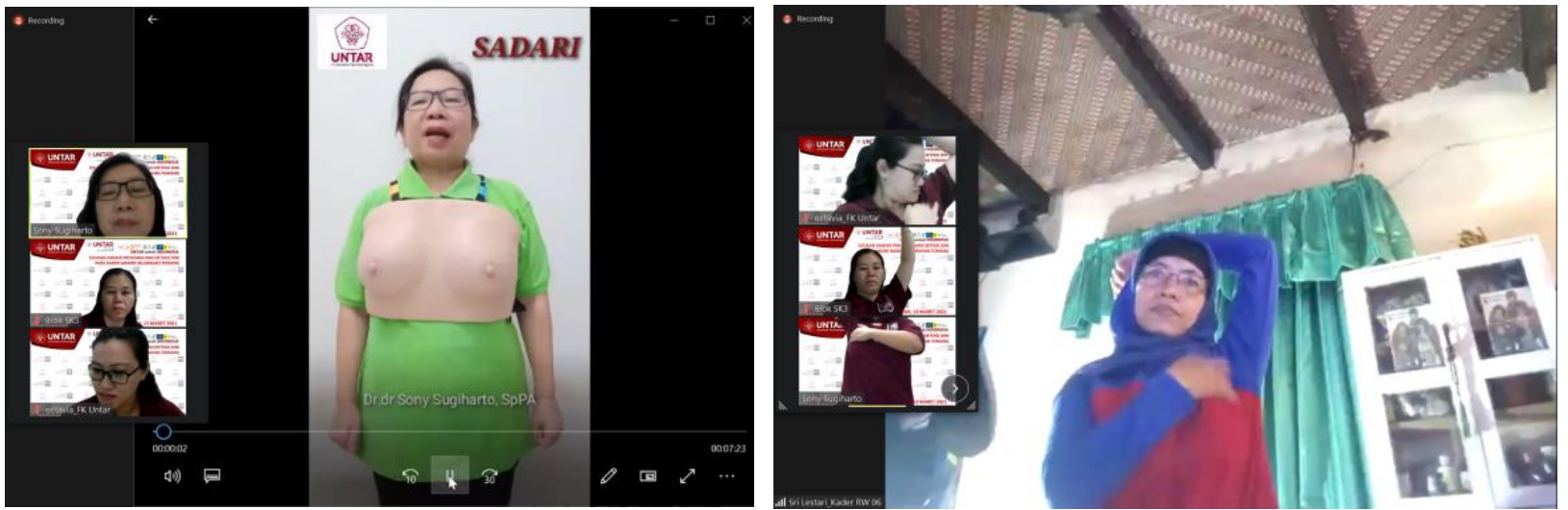


\section{Tabel 1}

Karakteristik Responden

\begin{tabular}{|c|c|}
\hline Variabel & Jumlah (\%) \\
\hline \multicolumn{2}{|l|}{ Umur (tahun) } \\
\hline$<45$ & $17(36,17)$ \\
\hline $46-65$ & $25(53,19)$ \\
\hline$>65$ & $5(10,64)$ \\
\hline \multicolumn{2}{|l|}{ Pendidikan } \\
\hline SD & $3(6,38)$ \\
\hline SMP & $7(14,90)$ \\
\hline SMA/ SMEA & $29(61,70)$ \\
\hline D3 & $1(2,12)$ \\
\hline $\mathrm{S} 1$ & $7(14,90)$ \\
\hline \multicolumn{2}{|c|}{ Materi mudah dimengerti } \\
\hline ya & $39(82,98)$ \\
\hline ragu-ragu & $8(17,02)$ \\
\hline tidak & $0(0)$ \\
\hline \multicolumn{2}{|c|}{ Materi sesuai harapan } \\
\hline ya & $39(82,98)$ \\
\hline ragu-ragu & $8(17,02)$ \\
\hline tidak & $0(0)$ \\
\hline \multicolumn{2}{|c|}{ Informasi yang disampaikan jelas } \\
\hline ya & $39(82,98)$ \\
\hline ragu-ragu & $8(17,02)$ \\
\hline tidak & $0(0)$ \\
\hline \multicolumn{2}{|c|}{ Pembicara menguasai topik } \\
\hline ya & $39(82,98)$ \\
\hline ragu-ragu & $8(17,02)$ \\
\hline tidak & $0(0)$ \\
\hline \multicolumn{2}{|c|}{ Pembicara dapat menjawab pertanyaan dengan baik dan jelas } \\
\hline ya & $39(82,98)$ \\
\hline ragu-ragu & $8(17,02)$ \\
\hline tidak & $0(0)$ \\
\hline \multicolumn{2}{|c|}{ Diskusi meningkatkan pemahaman peserta } \\
\hline ya & $39(82,98)$ \\
\hline ragu-ragu & $8(17,02)$ \\
\hline Tidak & $0(0)$ \\
\hline \multicolumn{2}{|c|}{ Alokasi waktu penyampaian materi dan diskusi mencukupi } \\
\hline уа & $39(82,98)$ \\
\hline ragu-ragu & $8(17,02)$ \\
\hline tidak & $0(0)$ \\
\hline \multicolumn{2}{|c|}{ Peserta akan melakukan SADARI } \\
\hline ya & $39(82,98)$ \\
\hline ragu-ragu & $8(17,02)$ \\
\hline tidak & $0(0)$ \\
\hline \multicolumn{2}{|c|}{ Peserta akan mengajarkan SADARI pada warga lain } \\
\hline уа & $37(78,72)$ \\
\hline ragu-ragu & $10(21,28)$ \\
\hline tidak & $0(0)$ \\
\hline \multicolumn{2}{|c|}{ Penyuluhan ini bermanfaat } \\
\hline ya & $39(82,98)$ \\
\hline ragu-ragu & $8(17,02)$ \\
\hline tidak & $0(0)$ \\
\hline
\end{tabular}

Sebanyak 10 (21,27\%) peserta belum mengetahui tentang SADARI, $22(46,81 \%)$ peserta tidak tahu cara melakukan SADARI, $27(57,45 \%)$ tidak rutin melakukan SADARI, dan 29 (61.70\%) peserta tidak mengetahui apa yang harus dilakukan jika menemukan benjolan pada SADARI. Rata-rata skor yang didapatkan saat pre-test dan post-test untuk menilai tingkat pengetahuan 
adalah 60.58 (SD 33.14) dan 84.58 (SD 7.87) dengan nilai p 0.532. Terlihat adanya peningkatan pengetahuan setelah penyuluhan sebesar 24 poin, namun perbedaannya tidak bermakna. Tingkat pengetahuan peserta cukup baik, namun tidak diiringi dengan kesadaran untuk melakukan SADARI, sehingga edukasi berupa penyuluhan, demonstrasi, dan praktik SADARI yang dilakukan ini cukup efektif. Hal ini sejalan dengan penyuluhan yang dilakukan dengan metode yang sama, terlihat adanya peningkatan pengetahuan sebelum dan sesudah penyuluhan, dengan rerata 2,92 (SD 15,79) dan nilai $\mathrm{p}=0,03$ (Wantini, 2016). Kegiatan serupa yang dilakukan oleh Yulinda \& Fitriyah (2018) juga menunjukkan hasil yang sama (nilai $\mathrm{p}=0,000$ ) dengan metode ceramah dan audiovisual. Pemilihan media dalam penyampaian edukasi kesehatan merupakan faktor yang berperan penting dalam keberhasilan proses edukasi. Metode yang dilakukan dalam kegiatan ini terlihat efektif karena adanya praktik langsung setelah ceramah dan demonstrasi SADARI.

\section{KESIMPULAN DAN SARAN}

Kegiatan PKM berjalan lancar pada tanggal 13 Maret 2021, diikuti oleh 47 orang pengurus PKK dan kader wanita Kelurahan Tomang secara daring. Usia responden adalah $22-76$ tahun, dengan rata-rata 48 tahun. Sebanyak 39 (82,98\%) peserta berpendapat materi mudah dipahami, sesuai harapan, informasi yang disampaikan jelas, pembicara menguasai topik serta dapat menjawab pertanyaan dengan baik dan jelas, diskusi membantu meningkatkan pemahaman peserta, alokasi waktu penyampaian materi dan diskusi mencukupi. Sebanyak $39(82,98 \%)$ orang dapat melakukan SADARI setelah penyuluhan dan sebanyak $37(78,72 \%)$ orang akan mengajarkan SADARI kepada warga Tomang lainnya. Sebanyak $39(82,98 \%)$ responden menganggap penyuluhan ini bermanfaat. Rata-rata skor yang didapatkan saat pre-test dan post-test untuk menilai tingkat pengetahuan adalah 60.58 (SD 33.14) dan 84.58 (SD 7.87) dengan nilai p 0.532. Terlihat adanya peningkatan pengetahuan setelah penyuluhan sebesar 24 poin, namun perbedaannya tidak bermakna. Diharapkan melalui pengenalan tanda-tanda kanker payudara, SADARI, dan rujukan yang tepat, kasus kanker payudara dapat diketahui lebih cepat sehingga mendapatkan penanganan sesegera mungkin, dan membuat prognosis dan kualitas hidup penderitanya lebih baik lagi.

Berdasarkan evaluasi kegiatan yang telah diselenggarakan, pihak mitra berharap kegiatan edukasi ini dilakukan secara rutin, sehingga dapat melakukan kegiatan pengabdian berkelanjutan. Topik kesehatan berikutnya yang diinginkan adalah kanker serviks dan kesehatan organ reproduksi, dan PKM ini dapat dikembangkan untuk penelitian berbasis pengabdian.

\section{Ucapan Terima Kasih (Acknowledgement)}

Kami mengucapkan terima kasih kepada Yayasan Tarumanagara, Rektor Universitas Tarumanagara, Ketua LPPM UNTAR, Dekan Fakultas Kedokteran Universitas Tarumanagara; serta pihak mitra, yaitu Lurah, pengurus PKK dan kader wanita Kelurahan Tomang yang telah membantu terlaksananya kegiatan penyuluhan ini.

\section{REFERENSI}

Badan Pusat Statistik Kota Jakarta Barat. (2021). Kecamatan grogol petamburan dalam angka 2017.https://jakbarkota.bps.go.id/publication/2017/09/27/07f7ea9833610c16facc84e1/keca mata n-grogol-petamburan-dalam-angka-2017.html

Bray, F., Ferlay, J., Soerjomataram, I., Siegel, R. L., Torre, L. A., \& Jemal, A. (2018). Global cancer statistics 2018: GLOBOCAN estimates of incidence and mortality worldwide for 36 cancers in 185 countries. CA: A Cancer Journal for Clinicians, 68(6), 394-424. https://doi.org/10.3322/caac.21492

Breast Cancer Risk Factors. (2020). https://www.breastcancer.org/symptoms/understand_bc 


\section{/risk/factors}

Dinas Komunikasi, Informatika dan Statistik Pemprov DKI Jakarta. (2017). Grogol Petamburan, Kecamatan. https://jakarta.go.id/artikel/konten/1295/grogol-petamburan-kecamatan

Fan, L., Goss, P. E., \& Strasser-Weippl, K. (2015). Current Status and Future Projections of Breast Cancer in Asia. Breast Care, 10(6), 372-378. https://doi.org/10.1159/000441818

Haliloglu, N., Ustuner, E., \& Ozkavukcu, E. (2019). Breast Ultrasound during Lactation: Benign and Malignant Lesions. Breast Care, 14(1), 30-34. https://doi.org/10.1159/000491781

Johnson, R. E., \& Murad, M. H. (2009). Gynecomastia: Pathophysiology, Evaluation, and Management. Mayo Clinic Proceedings, 84(11), 1010-1015.

Kementerian Kesehatan RI. (2015). Panduan program nasional gerakan pencegahan dan deteksi dini kanker leher Rahim dan kanker payudara. http://p2ptm.kemkes.go.id/uploads/2016/10/Panduan-Program-Nasional-GerakanPencegahan-dan-Deteksi-Dini-Kanker-Kanker-Leher-Rahim-dan-Kanker-Payudara-21April-2015.pdf.

Kementerian Kesehatan RI. (2016). Laporan riset penyakit tidak menular: tumor payudara dan lesi prakanker serviks. https://labmandat.litbang.kemkes.go.id/riset-badanlitbangkes/menu-riskesnas/menu- rikus/424-rptm-2016

Kementerian Kesehatan RI. (2019). Infodatin: Beban kanker di Indonesia. https://pusdatin.kemkes.go.id/ resources/download/pusdatin/infodatin/Infodatin- Kanker2019.pdf

Kementerian Kesehatan RI. (2019). Hari kanker sedunia 2019. https://www.kemkes.go.id/ article/view/19020100003/hari-kanker-sedunia-2019.html.

Kementerian Kesehatan RI. (2020). Jenis Kanker Ini Rentan Menyerang Manusia. Retrieved February 15, 2021, from_https://www.kemkes.go.id/article/view/20011400002/jeniskanker-ini-rentan-menyerang- manusia.html

Palu, M. B., Maidin, A., Sudirman, I., \& Nurdin, A. A. (2013). The Total Economic Burden of Breast Cancer in Makassar South Sulawesi, Indonesia. International Journal of Engineering Research, 2(9), 11.

RKBR Januari 2020 - canreg.fk.ugm.ac.id. (n.d.). https://canreg.fk.ugm.ac.id/laporandata/registrasi-kanker-berbasis-rumah-sakit-dr- sardjito-fkkmk-ugm/januari-2020/

Stachs, A., Stubert, J., Reimer, T., \& Hartmann, S. (2019). Benign Breast Disease in Women. Deutsches Ärzteblatt International, 116(33-34), 565-574. https://doi.org/10.3238/arztebl.2019.0565

Sung, H. , Ferlay, J., Siegel, R.L., Laversanne, M., Soerjomataram, I., Jemal, A., Bray, F. (2021). Global cancer statistics 2020: GLOBOCAN estimates of incidence and mortality worldwide for 36 cancers in 185 countries. CA: A Cancer Journal for Clinicians, 0(0), 1- 41. https://doi.org/10.3322/caac. 21660

The Global cancer observatory. (2020). https://gco.iarc.fr/today/data/factsheets/populations/360indonesia-fact-sheets.pdf.

TP PKK Tomang. (n.d.). https://pkktomang.wordpress.com/about

Wantini, N.A. (2016). Penyuluhan deteksi dini kanker payudara dengan periksa payudara sendiri (Sadari) Di Dusun Candirejo, Tegaltirto, Berbah, Sleman. RAKERNAS AIPKEMA 2016 "Temu Ilmiah Hasil Penelitian dan Pengabdian Masyarakat" YKPI. (2013). Home: YKPI https://www.pitapink- ykpi.or.id

Yulinda, A. \& Fitriyah, N. (2018). Efektivitas penyuluhan metode ceramah dan audiovisual dalam meningkatkan pengetahuan dan sikap tentang sadari di SMKN 5 Surabaya. Jurnal Promkes, 6 (2), 116 - 128. 